Sains Malaysiana 49(2)(2020): 293-303

http://dx.doi.org/10.17576/jsm-2020-4902-07

\title{
Mineral Contents of Chickpea Cultivars (Cicer arietinum L.) Grown at Different Locations of Turkey
}

(Kandungan Mineral Tanaman Kultivar Kacang Kuda (Cicer arietinum L.) di Lokasi Berbeza di Turki)

\author{
Özge Doganay ERBas Kose* \& ZeKI Mut
}

\begin{abstract}
Mineral deficiency-induced diseases and health problems influence billions of people worldwide. Development of edible legumes with high mineral contents will provide significant contributions in reducing the frequency of such diseases. Among the edible legumes, chickpea has quite high nutritional values and quite low production costs, thus commonly grown and consumed worldwide. This study was conducted to determine mineral (potassium, phosphorus, sulphur, calcium, magnesium, sodium, zinc, iron, boron, manganese, copper) contents of eight different chickpea cultivars (Akçin-91, Azkan, Hisar, Akça, Gökçe, Yaşa-05, Işık-05 and Çakır) grown in two different locations (Afyonkarahisar and Yozgat provinces of Turkey) for two years (2015 and 2016). Experiments were conducted in randomized blocks design with three replications. Among the minerals, potassium was highest (6435.2-8231.7 $\mathrm{mg} \mathrm{kg}^{-}$) followed by phosphorus (2573.9-3094.0 $\mathrm{mg} \mathrm{kg}^{-1}$ ) and sulphur (1710.9-2060.7 $\left.\mathrm{mg} \mathrm{kg}^{-1}\right)$. Among the minerals, copper was lowest followed by boron and manganese. Considering the average of locations, it was observed that Gökçe, Akçin-91, Azkan and Hisar cultivars were prominent with sulphur content; Akça with boron, sodium and calcium contents; Yaşa-05 and Işı-05 with potassium, phosphorus, magnesium, zinc, iron, magnesium, manganese and copper contents. Çakır cultivar was stable for all minerals. The concentrations of seed $P, S, C a, M g, B$ and $M n$ were significantly affected by locations.
\end{abstract}

Keywords: Cultivar; mineral; potassium; quality

\section{ABSTRAK}

Penyakit disebabkan kurang mineral dan masalah kesihatan mempengaruhi berbilion orang di seluruh dunia. Pembangunan kekacang yang boleh dimakan dengan kandungan mineral yang tinggi akan memberi sumbangan yang besar dalam mengurangkan kekerapan penyakit tersebut. Antara kekacang yang boleh dimakan, kacang kuda mempunyai nilai nutrisi yang agak tinggi dengan kos pengeluaran yang agak rendah dan umumnya ditanam dan dimakan di seluruh dunia. Kajian ini dijalankan untuk mengenal pasti kandungan mineral (kalium, fosforus, sulfat, kalsium, magnesium, natrium, zink, besi, boron, mangan, kuprum) lapan jenis kacang kuda berbeza kultivar (Akçin-91, Azkan, Hisar, Akça, Gökçe, Yaşa-05, Işık-05 dan Çakır) ditanam di dua lokasi berbeza (Wilayah Afyonkarahisar dan Yozgat, Turki) selama dua tahun (2015 dan 2016). Uji kaji telah dijalankan dalam reka bentuk blok rawak dengan tiga replikasi. Antara mineral, kalium adalah tertinggi (6435.2-8231.7 $\left.\mathrm{mg} \mathrm{kg}^{-1-}\right)$ diikuti dengan fosforus $(2573.9-3094.0 \mathrm{mg}$ $\left.\mathrm{kg}^{-1}\right)$ dan sulfat (1710.9-2060.7 $\left.\mathrm{mg} \mathrm{kg}^{-1}\right)$. Antara mineral, kuprum adalah paling rendah diikuti dengan boron dan mangan. Mengambil kira purata lokasi, telah diperhatikan bahawa kultivar Gökçe, Akçin-91, Azkan dan Hisar menonjol dengan kandungan sulfat; Akça dengan boron, natrium dan kandungan kalsium; Yaşa-05 dan Işı-05 dengan kalium, fosforus, magnesium, zink, besi, mangan dan kandungan kuprum. Kultivar Çakır adalah stabil untuk semua mineral. Kepekatan benih P, S, Ca, Mg, B dan Mn dengan ketara terjejas disebabkan lokasi.

Kata kunci: Kalium; kualiti; kultivar; mineral

\section{INTRODUCTION}

Mineral deficiency-induced diseases and health problems influence billions of people worldwide. Mineral deficiencies are commonly treated with diet supplements or supplemented foodstuffs. They are quite rich in carbohydrates, proteins, vitamins and minerals (Wang et al. 2010). Legumes have an irreplaceable place in vegetarian diets of developing countries; they have low glycemic index for patients with diabetes (Viswanathan \& Sudha 1989) and they have several positive health impacts including prevention of cancer (Hangen \& Bennink 2002) and cardiovascular diseases (Lee et al. 1992). Development of legume species with high mineral contents will contribute to reduce frequency of such diseases.

With regard to nutritional attributes, chickpea is among the most significant plants. With about 14 million tons of annual production, it has the third place in edible legumes worldwide. On the other hand, in Turkey, with 630 thousand tons of annual production, chickpea has the first place in edible legumes of the country (FAO 2017; TUIK 2017). Chickpea is quite rich in minerals; $100 \mathrm{~g}$ of it contains $875 \mathrm{mg}$ potassium, $331 \mathrm{mg}$ phosphorus, 105 $\mathrm{mg}$ calcium, $24 \mathrm{mg}$ sulphur, $11.5 \mathrm{mg}$ magnesium, $8.2 \mathrm{mg}$ selenium, $6.2 \mathrm{mg}$ iron and $3.4 \mathrm{mg}$ zinc (Khetarpaul 2018). 
With these values, entire $\mathrm{Fe}$ and $\mathrm{Zn}$ needs and half of $\mathrm{Mg}$ needs of daily diets are met (Jukanti et al. 2012). Chickpea is also a good source of carbohydrates (38.01-59.0\%) and proteins (14.9-24.6\%) (Yalçın et al. 2018). Chickpea with a well-balanced amino acid, high protein digestibility and low anti-nutritional attributes, thus accepted as a suitable source of diet for (Wood \& Grusak 2007). Just because of increasing world population, limited production sources, imbalanced resource allocations and high-costs of animaloriginated proteins, almost half of world population is undernourished. Chickpea with high nutritive values and low cost of production, thus has commonly consumed worldwide.

Cultivar selection in chickpea is generally performed based on agronomic traits. Effects of genetics, environment and their interactions on mineral composition should be determined while selecting chickpea cultivars with high mineral contents. In this study, field experiments were conducted with eight common chickpea cultivars of Turkey at two different locations (Afyonkarahisar and Yozgat provinces) for two years (2015 and 2016) and mineral composition of these chickpea cultivars were determined.

\section{MATERIALS AND METHODS}

\section{SEED MATERIALS}

In this study, eight commonly grown chickpea cultivars of Turkey (Akçin-91, Azkan, Hisar, Akça, Gökçe, Yaşa-05, Iş1k-05 and Çakır) were used as the plant material.

\section{FIELD EXPERIMENT}

Experiments were conducted at two different locations (experimental fields of Bozok University at Yerköy town of Yozgat province and farmer fields at Çay town of Afyonkarahisar province) for two years (2015 and 2016). Altitude is $1.021 \mathrm{~m}$ in Afyonkarahisar location and $771 \mathrm{~m}$ in Yozgat location. In both locations, sowings were performed in April. Harvest was performed on 16 August of the first year and 28 July of the second year in Afyonkarahisar location; on 5 August of the first year and 15 August of the second year in Yozgat location.

Climate data for experimental years are provided in Table 1. Throughout the vegetation period, total precipitation was $167.4 \mathrm{~mm}$, average temperature was $18.9^{\circ} \mathrm{C}$ and average relative humidity was $65.0 \%$ in Afyonkarahisar; the values, respectively, were $193.0 \mathrm{~mm}$, $16.62^{\circ} \mathrm{C}$ and $53.7 \%$ in Yozgat.

Soil characteristics of the experimental locations were identical in both years. Soil samples were taken from 0-30 $\mathrm{cm}$ soil profile and analysis results are provided in Table 2 .

\section{SAMPLES PREPARATION AND ANALYTICAL METHODS}

Harvested chickpea seeds stored at $4^{\circ} \mathrm{C}$ until analysis. The seeds were oven dried at $55^{\circ} \mathrm{C}$ and ground in a cyclone sample. Ground samples were then weighed into tared porcelain crucibles ( $2 \mathrm{~g}$ in each). Ash oven was gradually brought to $550^{\circ} \mathrm{C}$ and Ash was determined by incineration of known weights of the chickpea flour samples in a muffle furnace at $550^{\circ} \mathrm{C}$ for $8 \mathrm{~h}$. Samples were cooled in

TABLE 1. Meteorological data for the experiment areas

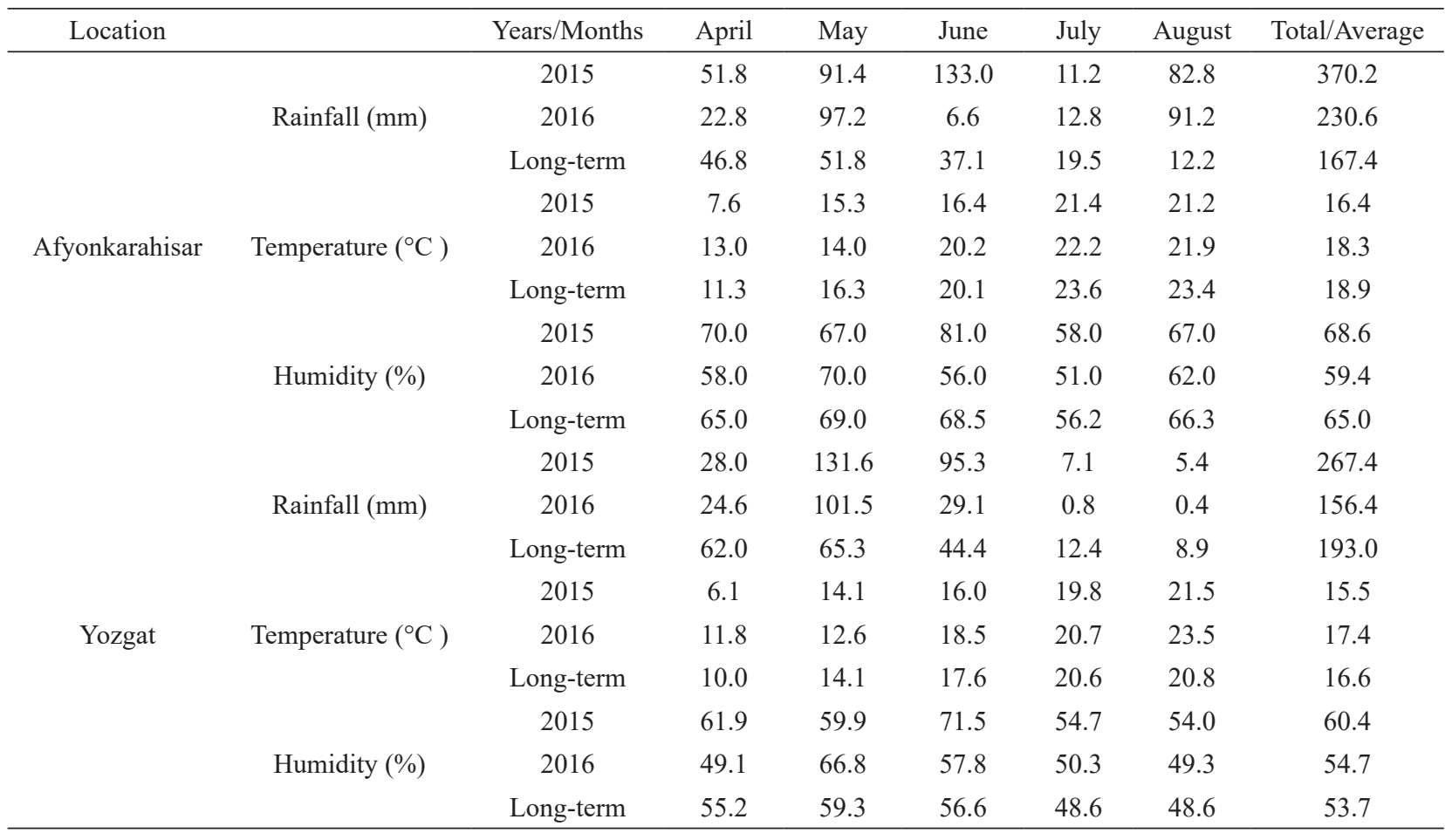


TABLE 2. Soil characteristics in the experimental areas*

\begin{tabular}{lcccc}
\hline Characteristics & \multicolumn{2}{c}{ Afyonkarahisar } & Yozgat \\
\hline Potassium $\left(\mathrm{kg} \mathrm{ha}^{-1}\right)$ & 222.3 & high & 49.3 & high \\
Phosphorus $\left(\mathrm{kg} \mathrm{ha}^{-1}\right)$ & 8.46 & medium & 8.30 & medium \\
Lime (\%) & 4.4 & lime & 7.4 & medium line \\
Organic matter (\%) & 1.63 & low & 1.7 & low \\
Salinity (\%) & 0.021 & saltless & 0.014 & saltless \\
pH & 7.7 & slightly alkaline & 8.4 & slightly alkaline \\
Saturation (\%) & 57.0 & clay-loam & 55.9 & clay-loam \\
\hline
\end{tabular}

* Yozgat agriculture chamber laboratory

desiccators and supplemented with $4 \mathrm{~mL} 3 \mathrm{~N} \mathrm{HCl}$. Samples were placed over hot-plate for about 10-15 min and they were filtered through filter papers into $100 \mathrm{~mL}$ polyethylene tubes with the aid of distilled water. Tubes were then completed to $100 \mathrm{~mL}$ with ultra-distilled water (Kaçar 1984). Resultant solutions were subjected to potassium $(\mathrm{K})$, phosphorus $(\mathrm{P})$, sulphur $(\mathrm{S})$, calcium $(\mathrm{Ca})$, magnesium $(\mathrm{Mg})$, sodium $(\mathrm{Na})$, zinc $(\mathrm{Zn})$, iron $(\mathrm{Fe})$, boron $(\mathrm{B})$, manganese $(\mathrm{Mn})$ and copper $(\mathrm{Cu})$ analyses with the aid of Inductive Coupled Plasma - Mass Spectrophotomer (ICPMS) device at Laboratories of Scientific and Technology Implementation and Research Center of Bozok University.

\section{STATISTICAL ANALYSIS}

Experiments were conducted in randomized complete blocks design with three replications (Gomez \& Gomez 1984). Separate and combined statistical analyses of the locations were performed with SAS software (SAS 1998).
Means were compared with Tukey's test. Simple correlations were computed between different minerals using the SPSS 16.0 packet program. Biplot graph was generated with the use of MultBiplotsoftware.

\section{RESULTS AND DISCUSSION}

Experiments were conducted with eight different chickpea cultivars at two different locations (Afyonkarahisar and Yozgat) for two years (2015 and 2016). Variance analysis results for investigated traits are provided in Table 3; mean values of investigated traits are provided in Tables 4 and 5; correlations between the investigated traits are provided in Table 6 and resultant biplot graph is presented in Figure 1.

\section{POTASSIUM (K) CONTENT}

With regard to potassium contents, differences between the cultivars were found to be significant in Afyonkarahisar

TABLE 3. Variance analyses of the investigated mineral matters

\begin{tabular}{|c|c|c|c|c|c|c|c|c|c|c|c|}
\hline General & $\mathrm{K}$ & $\mathrm{P}$ & $\mathrm{S}$ & $\mathrm{Ca}$ & $\mathrm{Mg}$ & $\mathrm{Na}$ & $\mathrm{Zn}$ & $\mathrm{Fe}$ & $\mathrm{B}$ & $\mathrm{Mn}$ & $\mathrm{Cu}$ \\
\hline & \multicolumn{11}{|c|}{ Afyonkarahisar } \\
\hline Year (Y) & ns & ns & ns & $* *$ & $*$ & ns & $* *$ & $* *$ & $* *$ & $* *$ & $* *$ \\
\hline Cultivar (C) & $* *$ & $*$ & ns & $* *$ & $* *$ & $* *$ & ns & $* *$ & $* *$ & $* *$ & $* *$ \\
\hline \multirow[t]{2}{*}{$\mathrm{Y} \times \mathrm{C}$} & $*$ & $* *$ & ns & ns & $*$ & $* *$ & $* *$ & $*$ & $*$ & ns & $* *$ \\
\hline & \multicolumn{11}{|c|}{ Yozgat } \\
\hline Year (Y) & ns & $*$ & $* *$ & $* *$ & $* *$ & ns & $* *$ & ns & ns & $* *$ & ns \\
\hline Cultivar (C) & $* *$ & $*$ & $*$ & $*$ & $* *$ & ns & $* *$ & $* *$ & ns & $* *$ & $* *$ \\
\hline \multirow[t]{2}{*}{$\mathrm{Y} \times \mathrm{C}$} & $* *$ & $* *$ & $* *$ & ns & $* *$ & $*$ & $* *$ & $*$ & $*$ & ns & $* *$ \\
\hline & \multicolumn{11}{|c|}{ Mean } \\
\hline Year (Y) & $\mathrm{ns}$ & ns & $\mathrm{ns}$ & $*$ & ns & ns & $* *$ & ns & $*$ & $* *$ & ns \\
\hline Location (L) & $* *$ & ns & $*$ & $* *$ & $* *$ & ns & ns & ns & $* *$ & $* *$ & ns \\
\hline $\mathrm{Y} \times \mathrm{L}$ & ns & $*$ & $*$ & $* *$ & $* *$ & ns & $*$ & $* *$ & ns & $* *$ & $* *$ \\
\hline Cultivar(C) & $* *$ & $* *$ & $*$ & $* *$ & $* *$ & $* *$ & $* *$ & $* *$ & $* *$ & $* *$ & $* *$ \\
\hline $\mathrm{Y} \times \mathrm{C}$ & $* *$ & $* *$ & $*$ & ns & $* *$ & $* *$ & $* *$ & $* *$ & $* *$ & ns & $* *$ \\
\hline $\mathrm{L} \times \mathrm{C}$ & ns & $*$ & $*$ & ns & $* *$ & $*$ & ns & $* *$ & ns & $* *$ & $* *$ \\
\hline $\mathrm{Y} \times \mathrm{L} \times \mathrm{C}$ & $*$ & $* *$ & $*$ & ns & $* *$ & $* *$ & $* *$ & ns & ns & ns & $* *$ \\
\hline
\end{tabular}

K: potassium, P: phosphorus, S: sulfur, Ca: calcium, Mg: magnesium, Na: sodium, Zn: zinc, Fe: Iron, B: boron, Mn: manganese, Cu: copper, ns: not significant, * Significant at $\mathrm{P}<0.05, * *$ Significant at $\mathrm{P}<0.01$ 
TABLE 4. Average of mineral matter contents of chickpea varieties grown in different locations (mg kg-1)

\begin{tabular}{|c|c|c|c|c|c|c|c|c|c|c|c|c|}
\hline \multirow[b]{3}{*}{ Çakır } & \multicolumn{6}{|c|}{$\mathrm{K}$ content } & \multicolumn{6}{|c|}{ P content } \\
\hline & \multicolumn{2}{|c|}{ Afyonkarahisar } & \multicolumn{2}{|c|}{ Yozgat } & \multicolumn{2}{|c|}{ Mean } & \multicolumn{2}{|c|}{ Afyonkarahisar } & \multicolumn{2}{|c|}{ Yozgat } & \multicolumn{2}{|c|}{ Mean } \\
\hline & 7190.0 & $\mathrm{~cd}$ & 7344.6 & $a b c$ & 7267.3 & $\mathrm{~cd}$ & 2573.9 & $\mathrm{c}$ & 2932.2 & $a b c$ & 2573.9 & $\mathrm{c}$ \\
\hline Akça & 7974.7 & $a b c$ & 7308.0 & $a b c$ & 7641.3 & $\mathrm{bc}$ & 2679.3 & $\mathrm{cb}$ & 2652.2 & $\mathrm{bc}$ & 2679.3 & $\mathrm{cb}$ \\
\hline Azkan & 7644.4 & abcd & 6342.9 & de & 6993.6 & de & 2964.5 & $a b$ & 2549.7 & $\mathrm{c}$ & 2964.5 & $a b$ \\
\hline Akçin-91 & 7444.8 & bcd & 6991.1 & $\mathrm{~cd}$ & 7217.9 & $\mathrm{~cd}$ & 2577.9 & $\mathrm{c}$ & 2752.2 & $a b c$ & 2577.9 & $\mathrm{c}$ \\
\hline Hisar & 6818.6 & d & 6051.8 & $\mathrm{e}$ & 6435.2 & e & 2628.6 & $\mathrm{c}$ & 2514.1 & $\mathrm{c}$ & 2628.6 & $\mathrm{c}$ \\
\hline Yaşa-05 & 8467.0 & $\mathrm{a}$ & 7943.2 & $\mathrm{ab}$ & 8205.1 & $\mathrm{ab}$ & 3094.0 & $\mathrm{a}$ & 3121.6 & a & 3094.0 & $\mathrm{a}$ \\
\hline Gökçe & 7929.6 & $a b c$ & 7066.6 & bcd & 7498.1 & $\mathrm{~cd}$ & 2815.2 & $a b c$ & 2571.5 & $\mathrm{c}$ & 2815.2 & $a b c$ \\
\hline Işı1k-05 & 8360.7 & $a b c$ & 8102.8 & $\mathrm{a}$ & 8231.7 & $\mathrm{a}$ & 2836.6 & $a b c$ & 3061.4 & $\mathrm{ab}$ & 2836.6 & $a b c$ \\
\hline \multirow[t]{3}{*}{ Mean } & 7728.7 & $b$ & 7143.9 & $a$ & \multicolumn{2}{|c|}{7436.3} & \multicolumn{2}{|c|}{2771.3} & \multicolumn{2}{|c|}{2769.4} & \multicolumn{2}{|c|}{2771.3} \\
\hline & \multicolumn{6}{|c|}{ S content } & \multicolumn{6}{|c|}{ Ca content } \\
\hline & \multicolumn{2}{|c|}{ Afyonkarahisar } & \multicolumn{2}{|c|}{ Yozgat } & \multicolumn{2}{|c|}{ Mean } & \multicolumn{2}{|c|}{ Afyonkarahisar } & \multicolumn{2}{|c|}{ Yozgat } & $\mathrm{Me}$ & \\
\hline Çakır & 1710.9 & & 1807.2 & $\mathrm{ab}$ & 1759.1 & $\mathrm{ab}$ & 972.5 & $\mathrm{~cd}$ & 1306.8 & $a b c$ & 1139.6 & $\mathrm{bc}$ \\
\hline Akça & 1786.2 & & 1710.9 & $\mathrm{ab}$ & 1748.6 & $\mathrm{ab}$ & 1259.3 & $\mathrm{a}$ & 1370.2 & $\mathrm{a}$ & 1314.8 & $\mathrm{a}$ \\
\hline Azkan & 1868.0 & & 1935.1 & $\mathrm{a}$ & 1901.5 & $\mathrm{a}$ & 1026.0 & bcd & 1102.2 & $\mathrm{bc}$ & 1064.1 & $\mathrm{~cd}$ \\
\hline Akçin-91 & 1868.8 & & 1763.4 & $a b$ & 1816.1 & $\mathrm{ab}$ & 1018.5 & bcd & 1079.0 & $\mathrm{c}$ & 1048.7 & $\mathrm{~cd}$ \\
\hline Hisar & 1821.0 & & 1942.4 & $\mathrm{a}$ & 1881.7 & $a b$ & 936.2 & d & 1089.8 & $\mathrm{bc}$ & 1013.0 & $\mathrm{~d}$ \\
\hline Yaşa-05 & 1938.4 & & 1614.3 & $\mathrm{~b}$ & 1776.3 & $a b$ & 1076.4 & $\mathrm{bc}$ & 1133.7 & $\mathrm{bc}$ & 1105.0 & $\mathrm{~cd}$ \\
\hline Gökçe & 2063.7 & & 1743.8 & $\mathrm{ab}$ & 1903.7 & $\mathrm{a}$ & 1021.7 & bcd & 1117.2 & $\mathrm{bc}$ & 1069.4 & $\mathrm{~cd}$ \\
\hline Işık-05 & 1805.5 & & 1635.9 & $\mathrm{~b}$ & 1720.7 & $\mathrm{~b}$ & 1125.9 & $\mathrm{~b}$ & 1322.5 & $\mathrm{ab}$ & 1224.2 & $a b$ \\
\hline Mean & 1857.8 & $a$ & 1769.1 & $b$ & 181 & & 1054.6 & $b$ & 1190.2 & $a$ & 112 & \\
\hline & & & $\mathrm{Mg}$ co & & & & & & $\mathrm{Na}$ co & & & \\
\hline & Afyonk & ahisar & Yoz & & $\mathrm{Me}$ & & Afyonk: & hisar & Yor & & $\mathrm{Me}$ & \\
\hline Çakır & 1046.6 & $\mathrm{c}$ & 1141.2 & $\mathrm{a}$ & 1093.9 & $\mathrm{bc}$ & 496.5 & $\mathrm{c}$ & 565.5 & & 531.0 & bcd \\
\hline Akça & 1287.4 & $\mathrm{a}$ & 1042.3 & $\mathrm{ab}$ & 1164.9 & $\mathrm{ab}$ & 786.5 & $\mathrm{a}$ & 641.6 & & 714.0 & $\mathrm{a}$ \\
\hline Azkan & 1166.5 & $\mathrm{~b}$ & 890.8 & $\mathrm{~b}$ & 1028.6 & cde & 648.2 & $\mathrm{~b}$ & 441.3 & & 544.7 & bcd \\
\hline Akçin-91 & 1027.0 & $\mathrm{c}$ & 968.5 & $\mathrm{~b}$ & 996.2 & de & 430.2 & $\mathrm{c}$ & 490.8 & & 460.5 & $\mathrm{~d}$ \\
\hline Hisar & 1024.5 & $\mathrm{c}$ & 906.7 & $\mathrm{~b}$ & 967.1 & $\mathrm{e}$ & 514.5 & $\mathrm{c}$ & 520.0 & & 517.2 & bcd \\
\hline Yaşa-05 & 1226.4 & $a b$ & 1151.6 & $\mathrm{a}$ & 1189.0 & $\mathrm{a}$ & 505.2 & $\mathrm{c}$ & 693.1 & & 599.2 & $a b c$ \\
\hline Gökçe & 1120.0 & $\mathrm{bc}$ & 993.0 & $\mathrm{~b}$ & 1056.5 & $\mathrm{~cd}$ & 482.6 & $\mathrm{c}$ & 480.6 & & 481.6 & $\mathrm{~cd}$ \\
\hline Iş1k-05 & 1172.6 & $\mathrm{ab}$ & 1144.8 & $\mathrm{a}$ & 1158.7 & $\mathrm{ab}$ & 551.6 & $\mathrm{bc}$ & 709.8 & & 630.7 & $\mathrm{ab}$ \\
\hline Mean & 1133.9 & $a$ & 1029.9 & $b$ & 108 & & 55 & & 56 & & 559 & \\
\hline & & & $\mathrm{Zn} \mathrm{col}$ & & & & & & $\mathrm{Fe} \mathrm{co}$ & & & \\
\hline & Afyonk & ahisar & Yoz & & $\mathrm{Me}$ & & Afyonk & hisar & Yor & & $\mathrm{Me}$ & \\
\hline Çakır & 19.68 & & 22.14 & $\mathrm{~b}$ & 20.91 & $\mathrm{~b}$ & 42.10 & $\mathrm{bc}$ & 45.30 & $\mathrm{bc}$ & 43.70 & $\mathrm{bc}$ \\
\hline Akça & 18.79 & & 18.88 & $\mathrm{~b}$ & 18.84 & $\mathrm{~b}$ & 44.50 & $a b c$ & 40.80 & bcd & 42.60 & $\mathrm{~cd}$ \\
\hline Azkan & 20.03 & & 19.32 & $\mathrm{~b}$ & 19.68 & $\mathrm{~b}$ & 44.40 & $a b c$ & 37.80 & $\mathrm{~d}$ & 41.10 & $\mathrm{~cd}$ \\
\hline Akçin-91 & 19.15 & & 21.30 & $\mathrm{~b}$ & 20.23 & $\mathrm{~b}$ & 42.80 & $a b c$ & 41.30 & bcd & 42.10 & $\mathrm{~cd}$ \\
\hline Hisar & 18.84 & & 19.49 & $\mathrm{~b}$ & 19.17 & $\mathrm{~b}$ & 41.60 & $\mathrm{c}$ & 39.00 & $\mathrm{~cd}$ & 40.30 & d \\
\hline Yaşa-05 & 21.15 & & 20.74 & $\mathrm{~b}$ & 20.94 & $\mathrm{~b}$ & 45.60 & $a b$ & 47.00 & $\mathrm{~b}$ & 46.30 & $\mathrm{~b}$ \\
\hline Gökçe & 20.93 & & 19.32 & $\mathrm{~b}$ & 20.12 & $\mathrm{~b}$ & 44.00 & $a b c$ & 40.90 & bcd & 42.40 & $\mathrm{~cd}$ \\
\hline Işık-05 & 21.02 & & 25.93 & $\mathrm{a}$ & 23.48 & $\mathrm{a}$ & 46.20 & $\mathrm{a}$ & 53.60 & $\mathrm{a}$ & 49.90 & $\mathrm{a}$ \\
\hline Mean & 19 & & 20 & & 20. & & 43. & & 43 & & 46. & \\
\hline
\end{tabular}




\begin{tabular}{|c|c|c|c|c|c|c|c|c|c|c|c|c|}
\hline \multirow[b]{3}{*}{ Çakır } & \multicolumn{6}{|c|}{ B content } & \multicolumn{6}{|c|}{ Mn content } \\
\hline & \multicolumn{2}{|c|}{ Afyonkarahisar } & \multicolumn{2}{|c|}{ Yozgat } & \multicolumn{2}{|c|}{ Mean } & \multicolumn{2}{|c|}{ Afyonkarahisar } & \multicolumn{2}{|c|}{ Yozgat } & \multicolumn{2}{|c|}{ Mean } \\
\hline & 14.08 & $\mathrm{bc}$ & 13.43 & & 13.76 & $\mathrm{bc}$ & 16.80 & $\mathrm{c}$ & 16.90 & $\mathrm{ab}$ & 16.85 & $\mathrm{~b}$ \\
\hline Akça & 15.27 & $\mathrm{a}$ & 14.33 & & 14.80 & $\mathrm{a}$ & 19.52 & $a b$ & 14.48 & bcd & 17.00 & $\mathrm{~b}$ \\
\hline Azkan & 14.42 & $a b$ & 12.65 & & 13.53 & $\mathrm{c}$ & 19.60 & $\mathrm{ab}$ & 14.27 & $\mathrm{~cd}$ & 16.93 & $\mathrm{~b}$ \\
\hline Akçin-91 & 14.05 & $\mathrm{bc}$ & 13.38 & & 13.72 & $\mathrm{bc}$ & 18.28 & $\mathrm{bc}$ & 14.82 & $a-d$ & 16.55 & $\mathrm{~b}$ \\
\hline Hisar & 13.47 & $\mathrm{c}$ & 12.88 & & 13.18 & $\mathrm{c}$ & 16.92 & $\mathrm{c}$ & 12.83 & $\mathrm{~d}$ & 14.88 & $\mathrm{c}$ \\
\hline Yaşa-05 & 14.02 & $\mathrm{bc}$ & 13.78 & & 13.90 & $\mathrm{bc}$ & 20.95 & $\mathrm{a}$ & 16.68 & $\mathrm{a}$ & 18.82 & $\mathrm{a}$ \\
\hline Gökçe & 14.43 & $a b$ & 12.72 & & 13.58 & $\mathrm{c}$ & 18.33 & $\mathrm{bc}$ & 14.42 & bcd & 16.38 & $\mathrm{~b}$ \\
\hline Iş1k-05 & 14.63 & $\mathrm{ab}$ & 14.33 & & 14.48 & $\mathrm{ab}$ & 18.43 & $\mathrm{bc}$ & 15.87 & $a b c$ & 17.15 & $\mathrm{~b}$ \\
\hline \multirow[t]{3}{*}{ Mean } & 14.25 & $a$ & 13.39 & $b$ & \multicolumn{2}{|c|}{13.83} & 18.67 & $a$ & 15.04 & $b$ & \multicolumn{2}{|c|}{16.82} \\
\hline & \multicolumn{6}{|c|}{$\mathrm{Cu}$ content } & & & & & & \\
\hline & \multicolumn{2}{|c|}{ Afyonkarahisar } & Yoz & & \multicolumn{2}{|c|}{ Mean } & & & & & & \\
\hline Çakır & 1710.9 & & 1807.2 & $a b$ & 1759.1 & $\mathrm{ab}$ & & & & & & \\
\hline Akça & 1786.2 & & 1710.9 & $a b$ & 1748.6 & $\mathrm{ab}$ & & & & & & \\
\hline Azkan & 1868.0 & & 1935.1 & $\mathrm{a}$ & 1901.5 & $\mathrm{a}$ & & & & & & \\
\hline Akçin-91 & 1868.8 & & 1763.4 & $a b$ & 1816.1 & $\mathrm{ab}$ & & & & & & \\
\hline Hisar & 1821.0 & & 1942.4 & $\mathrm{a}$ & 1881.7 & $\mathrm{ab}$ & & & & & & \\
\hline Yaşa-05 & 1938.4 & & 1614.3 & $\mathrm{~b}$ & 1776.3 & $\mathrm{ab}$ & & & & & & \\
\hline Gökçe & 2063.7 & & 1743.8 & $a b$ & 1903.7 & $\mathrm{a}$ & & & & & & \\
\hline Iş1k-05 & 1805.5 & & 1635.9 & $\mathrm{~b}$ & 1720.7 & $\mathrm{~b}$ & & & & & & \\
\hline Mean & \multicolumn{2}{|c|}{7.359} & \multicolumn{2}{|c|}{6.948} & \multicolumn{2}{|c|}{7.149} & & & & & & \\
\hline
\end{tabular}

and Yozgat locations. Since the year-based responses of the cultivars were different in both locations, year $\mathrm{x}$ cultivar interactions were also found to be significant (Table 3). In Afyonkarahisar, K contents varied between 6818.6 (Hisar) and 8467.0 (Yaşa-05) $\mathrm{mg} \mathrm{kg}^{-1}$ and the cultivars Akça, Azkan, Gökçe and Işık-05 were placed in the same statistical group with Yaşa-05 with the greatest $\mathrm{K}$ content. In Yozgat, $\mathrm{K}$ contents of the cultivars varied between 6051.8 (Hisar) and 8102.8 (Işık-05) $\mathrm{mg} \mathrm{kg}^{-1}$ and the cultivars Çakır, Akça and Yaşa-05 were placed in the same statistical group with Işık-05 with the greatest $\mathrm{K}$ content (Table 4).

Combined analyses on $\mathrm{K}$ contents showed significant differences between the locations and between the cultivars. Year $\times$ cultivar and year $\times$ location $\times$ cultivar interactions were found to be significant (Table 3 ). K contents of the cultivars varied between 6435.2 (Hisar) and 8231.7 (Işsk-05) $\mathrm{mg} \mathrm{kg}^{-1}$ with an average value of $7436.3 \mathrm{mg} \mathrm{kg}^{-1}$. K contents were lower in Afyonkarahisar than in Yozgat. Such a case indicated different responses of cultivars to different years and ecologies (Table 3). Potassium increases protein ratio of the plants and improves quality through uniform and early ripening of the kernels. Potassium also prevents shrinking of legume seeds (Kacar \& Katkat 1988). Average K content was greater in Afyonkarahisar (7728.7 $\mathrm{mg} \mathrm{kg}^{-1}$ ) than in Yozgat (7143.9 $\mathrm{mg} \mathrm{kg}^{-1}$ ) (Table 4). In previous studies, chickpea $\mathrm{K}$ contents were reported as between 239.0 - $263.0 \mathrm{mg}$ $100 \mathrm{~g}^{-1}$ (Haq et al. 2007), between 7480 - 7487 ppm (Ceran
2015), between 8711.5 - $9014.6 \mathrm{mg} \mathrm{kg}^{-1}$ (Kahraman et al. 2015) and between 4698 - $7423 \mathrm{mg} \mathrm{kg}^{-1}$ (Bayrak \& Onder 2017).

\section{PHOSPHORUS (P) CONTENT}

With regard to $\mathrm{P}$ content, cultivars were found to be significant in Afyonkarahisar; years and cultivars were found to be significant in Yozgat. Year $\times$ cultivar interactions were found to be significant in both locations (Table 3). In Afyonkarahisar, P contents varied between 2573.9 (Çakır) and 3121.6 (Yaşa-05) $\mathrm{mg} \mathrm{kg}^{-1}$ and the cultivars Azkan, Gökçe and Işık-05 were placed in the same statistical group with Yaşa-05 with the greatest $\mathrm{P}$ content. In Yozgat, P contents varied between 2514.1 (Hisar) and 3121.6 (Yaşa-05) $\mathrm{mg} \mathrm{kg}^{-1}$ and the cultivars Çakır, Akçin-91 and Işık-05 were placed in the same statistical group with Yaşa-05 with the greatest $\mathrm{P}$ content (Table 4). While the differences in P content of the years were not significant in Afyonkarahisar, average P content was $2869.5 \mathrm{mg} \mathrm{kg}^{-1}$ in 2015 and $2669.1 \mathrm{mg} \mathrm{kg}^{-1}$ in 2016 in Yozgat (Table 5). Such a case was attributed to greater precipitations in June 2015 in both locations.

Combined analyses on $\mathrm{P}$ contents showed significant differences between the cultivars. Year $\times$ location, year $\times$ cultivar, location $\times$ cultivar and year $\times$ location $\times$ cultivar interactions were found to be significant (Table 3 ). According to combined variance analysis, $\mathrm{P}$ contents of the cultivars varied between 2514.1 (Hisar) and 3107.8 
(Yaşa-05) $\mathrm{mg} \mathrm{kg}^{-1}$ with an average value of $2771.3 \mathrm{mg} \mathrm{kg}^{-1}$ (Table 4$)$. Significant year $\times$ cultivar and location $\times$ cultivar interactions were resulted from different responses of cultivars to years and locations. In previous studies, $\mathrm{P}$ contents of chickpea were reported as between 377.0 -

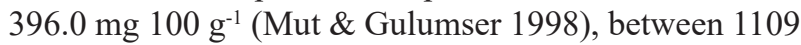

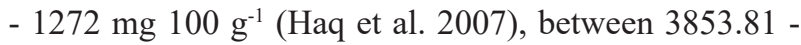
3572.91 ppm (Ceran 2015), between 2912.4 - $3379.9 \mathrm{mg}$ $\mathrm{kg}^{-1}$ (Kahraman et al. 2015), between $2257.01-3590.37$ $\mathrm{mg} \mathrm{kg}^{-1}$ (Bayrak \& Onder 2017) and between 3516 - 4246 ppm (Vandemark et al. 2018). Some other researchers

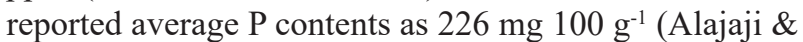

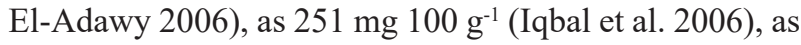
$423 \mathrm{mg} 100 \mathrm{~g}^{-1}$ (Wang et al. 2010) and as $2810 \mathrm{mg} \mathrm{kg}^{-1}$ (Haq et al. 2007). Phosphorus plays a great role in cell division, fruit and seed formation. Soil phosphorus levels, phosphorous fertilizers and bacteria inoculations may improve kernel phosphorus contents. Ceran (2015), reported that late-sowings increased kernel phosphorus contents.

\section{SULPHUR (S) CONTENT}

While there were not significant differences in $\mathrm{S}$ contents in Afyonkarahisar, years, cultivars and year $\times$ cultivar interactions were found to be significant in Yozgat (Table 3). In Afyonkarahisar, S contents varied between 1710.9 (Çakır) and 2063.7 (Gökçe) mg kg-1. In Yozgat, S contents varied between 1614.3 (Yaşa-05) and 1942.4 (Hisar) mg $\mathrm{kg}^{-1}$ and all cultivars, except for Yaşa-05 and Iş1k-05, were placed in the same statistical group (Table 4). In Yozgat, with significant years' averages interactions, $\mathrm{S}$ content was greater in the first year $\left(1848.5 \mathrm{mg} \mathrm{kg}^{-1}\right)$ than in the second year (1689.7 $\mathrm{mg} \mathrm{kg}^{-1}$ ) (Table 5).

Combined analyses showed significant differences between the locations and between the cultivars, thus year $\times$ location, year $\times$ cultivar, location $\times$ cultivar and year $\times$ location $\times$ cultivar interactions were found to be significant (Table 3 ). As the average of two years, S contents of the cultivars varied between 1710.9 (Çakır) and 2063.7 (Gökçe) $\mathrm{mg} \mathrm{kg}^{-1}$ with an average value of $1857.8 \mathrm{mg} \mathrm{kg}^{-1}$. Just because of differences in cultivar responses to different ecologies, S content was lower in Yozgat (1769.1 $\mathrm{mg} \mathrm{kg}^{-1}$ ) than in Afyonkarahisar (1857.8 $\mathrm{mg} \mathrm{kg}^{-1}$ ) (Table 4). Sulphur is a key component of amino acids (cysteine and methionine), thus a key component of proteins. Biological value of protein is reduced under sulphurous amino acid deficiency (Budag 2009). S contents of chickpea were reported as between 1808.6 - $1848.6 \mathrm{mg} \mathrm{kg}^{-1}$ (Kahraman et al. 2015), between 1790 - $2115 \mathrm{mg} \mathrm{kg}^{-1}$ (Vandemark et al. 2018), and as $1809 \mathrm{mg} \mathrm{kg}^{-1}$ (Ozcan et al. 2013).

\section{CALCIUM (CA) CONTENT}

With regard to $\mathrm{Ca}$ contents, significant differences were observed between the years and between the cultivars in both locations (Table 3). In Afyonkarahisar, Ca contents of the cultivars varied between 936.2 (Hisar) and 1259.3 (Akça) $\mathrm{mg} \mathrm{kg}^{-1}$ with greater $\mathrm{Ca}$ content in the first year (1152.4 $\left.\mathrm{mg} \mathrm{kg}^{-1}\right)$ than in the second year $\left(956.8 \mathrm{mg} \mathrm{kg}^{-1}\right)$. In Yozgat, Ca contents varied between 1079.0 (Akçin-91) and 1370.2 (Akça) $\mathrm{mg} \mathrm{kg}^{-1}$ with lower value in the first year $\left(1015.0 \mathrm{mg} \mathrm{kg}^{-1}\right)$ than in the second year $(1365.2 \mathrm{mg}$ $\mathrm{kg}^{-1}$ ) (Table 4).

Combined analyses showed significant differences between the years, locations and cultivars, year $\times$ location and year $\times$ location $\times$ cultivar interactions were also found to be significant (Table 3 ). As the average of two years, $\mathrm{Ca}$ contents of the cultivars varied between 1013.0 (Hisar) and 1314.8 (Akça) $\mathrm{mg} \mathrm{kg}^{-1}$ with a general average of 1122.4 $\mathrm{mg} \mathrm{kg}^{-1}$. Ca content was greater in Yozgat (1190.1 $\mathrm{mg} \mathrm{kg}^{-1}$ ) than in Afyonkarahisar $\left(1054.6 \mathrm{mg} \mathrm{kg}^{-1}\right)$ and also greater in the second year $\left(1161.0 \mathrm{mg} \mathrm{kg}^{-1}\right)$ than in the first year $\left(1083.7 \mathrm{mg} \mathrm{kg}^{-1}\right)$ (Tables 4 \& 5). It was reported that increasing $\mathrm{Ca}, \mathrm{Mg}$, pectin and lignin content of seed coat hindered water intake of the kernels and prolonged cooking durations (Akdag 2001). Seed germination increases with increasing seed calcium contents. In previous studies,

TABLE 5. Average of mineral matter contents of chickpea varieties grown in different years $\left(\mathrm{mg} \mathrm{kg}^{-1}\right)$

\begin{tabular}{ccccccc}
\hline \multirow{2}{*}{ Trails } & \multicolumn{3}{c}{2015 year } & \multicolumn{3}{c}{ 2016 year } \\
\cline { 2 - 7 } & Afyonkarahisar & Yozgat & Mean & Afyonkarahisar & Yozgat & Mean \\
\hline $\mathrm{K}$ & 7695.5 & 7047.6 & 7371.5 & 7761.9 & 7240.2 & 7501.0 \\
$\mathrm{P}$ & 2814.0 & 2869.5 & 2799.0 & 2728.4 & 2669.1 & 2741.5 \\
$\mathrm{~S}$ & 1841.0 & 1848.5 & 1844.7 & 1874.5 & 1689.7 & 1782.1 \\
$\mathrm{Ca}$ & 1152.4 & 1015.0 & 1083.7 & 956.8 & 1365.2 & 1161.0 \\
$\mathrm{Mg}$ & 1164.2 & 1102.6 & 1060.7 & 1103.5 & 957.2 & 1103.0 \\
$\mathrm{Na}$ & 574.9 & 564.3 & 569.6 & 528.9 & 571.3 & 550.1 \\
$\mathrm{Zn}$ & 20.84 & 22.90 & 21.87 & 19.06 & 18.89 & 18.97 \\
$\mathrm{Fe}$ & 45.38 & 42.20 & 43.79 & 42.50 & 44.30 & 43.40 \\
$\mathrm{~B}$ & 14.57 & 13.63 & 14.10 & 14.03 & 13.25 & 13.64 \\
$\mathrm{Mn}$ & 21.92 & 16.98 & 19.38 & 15.42 & 13.09 & 14.25 \\
$\mathrm{Cu}$ & 7.819 & 6.755 & 7.277 & 6.899 & 7.141 & 7.020 \\
\hline
\end{tabular}


chickpea Ca contents varied in a broad range and reported as between 746.8 and $2190.0 \mathrm{mg} \mathrm{kg}^{-1}$ (Alajaji \& El-Adawy 2006; Ceran 2015; Haq et al. 2007; Iqbal et al. 2006; Ozcan et al. 2013; Vandemark et al. 2018). Bueckert et al. (2011) carried out a study with 10 chickpea cultivars at two different locations and reported average Ca content as 2036 $\mathrm{mg} \mathrm{kg}^{-1}$ in Swift Current location and as $1660 \mathrm{mg} \mathrm{kg}^{-1}$ in Saskatoon location.

\section{MAGNESIUM (MG) CONTENT}

With regard to $\mathrm{Mg}$ contents, significant differences were observed between the years and cultivars in both locations. Year $\times$ cultivar interactions were also found to be significant in both locations (Table 3). In Afyonkarahisar, $\mathrm{Mg}$ contents of the cultivars varied between 1024.5 (Hisar) and 1287.4 (Akça) $\mathrm{mg} \mathrm{kg}^{-1}$ and the cultivars Yaşa-05 and Iş1k-05 were placed in the same statistical group with Akça with the greatest $\mathrm{Mg}$ content. In Yozgat, $\mathrm{Mg}$ contents varied between 890.8 (Azkan) and 1151.6 (Yaşa-05) $\mathrm{mg} \mathrm{kg}^{-1}$ and the cultivars Akça, Çakır and Işık-05 were also placed in the same statistical group with Yaşa-05 with the greatest Mg content (Table 4). Mg content of Afyonkarahisar and Yozgat locations was $1164.2 \mathrm{mg} \mathrm{kg}^{-1}$ and $1102.6 \mathrm{mg} \mathrm{kg}^{-1}$, respectively, in the first year and $1103.5 \mathrm{mg} \mathrm{kg}^{-1}$ and 957.2 $\mathrm{mg} \mathrm{kg}^{-1}$, respectively, in the second year (Table 5).

Combined analyses showed significant differences in $\mathrm{Mg}$ content of the cultivars. Year $\times$ location, year $\times$ cultivar, location $\times$ cultivar and year $\times$ location $\times$ cultivar interactions were also found to be significant (Table 3). As the average of two years, $\mathrm{Mg}$ contents varied between 967.1 (Hisar) and 1189.0 (Yaşa-05) $\mathrm{mg} \mathrm{kg}^{-1}$ with a general average of $1081.9 \mathrm{mg} \mathrm{kg}^{-1}$. $\mathrm{Mg}$ content was greater in Afyonkarahisar $\left(1133.9 \mathrm{mg} \mathrm{kg}^{-1}\right)$ than in Yozgat (1029.9 $\mathrm{mg} \mathrm{kg}^{-1}$ ) (Table 4). Magnesium plays a significant role in RNA and DNA mechanisms of cell nucleus, protein synthesis and enzyme activity. Legumes generally have quite high magnesium contents (Elinç 2007). In previous studies, $\mathrm{Mg}$ contents of chickpeas were reported as between 800 and $2112 \mathrm{mg} \mathrm{kg}^{-1}$ (Bayrak \& Onder 2017; Kahraman et al. 2015; Ozcan et al. 2013; Vandemark et al. 2018; Wang et al. 2010).

\section{SODIUM (NA) CONTENT}

Significant differences were observed in $\mathrm{Na}$ contents of the cultivars in Afyonkarahisar. Year $\times$ cultivar interactions were also found to be significant in both locations (Table 3). Na contents varied between 430.2 (Akçin-91) and 786.5 (Akça) $\mathrm{mg} \mathrm{kg}^{-1}$ in Afyonkarahisar and between 441.3 (Azkan) and 709.8 (Işık-05) $\mathrm{mg} \mathrm{kg}^{-1}$ in Yozgat. The differences in $\mathrm{Na}$ content of the years were not found to be significant in both locations (Table 4).

Combined analyses showed significant differences in $\mathrm{Na}$ contents of the cultivars. Year $\times$ cultivar, location $\times$ cultivar and year $\times$ location $\times$ cultivar interactions were also found to be significant (Table 3 ). As the average of two years, Na contents of the cultivars varied between
460.5 (Akçin-91) and 714.0 (Akça) $\mathrm{mg} \mathrm{kg}^{-1}$ with a general average of $559.9 \mathrm{mg} \mathrm{kg}^{-1}$. The cultivars Yaşa-05 and Işık05 were also placed in the same statistical group with Akça with the greatest $\mathrm{Na}$ content (Table 4). Previous researchers reported average $\mathrm{Na}$ content as 960 ppm (Haq et al. 2007), as 1003 ppm (Daur et al. 2008), as 1073.4 ppm (Arab et al. 2010), and as $398.1 \mathrm{mg} \mathrm{kg}^{-1}$ (Ozcan et al. 2013). Such differences were mainly attributed to ecological factors, soil texture, agricultural practices and genetics.

\section{ZINC (ZN) CONTENT}

Significant differences were observed in $\mathrm{Zn}$ contents of the years and cultivars in both locations. Year $\times$ cultivar interactions were also found to be significant in both locations. Zn contents varied between 18.79 (Akça) and 21.15 (Yaşa-05) $\mathrm{mg} \mathrm{kg}^{-1}$ in Afyonkarahisar and between 18.88 (Akça) and 25.93 (Iş1k-05) $\mathrm{mg} \mathrm{kg}^{-1}$ in Yozgat location. Zn contents of Afyonkarahisar and Yozgat locations were observed as $20.84 \mathrm{mg} \mathrm{kg}^{-1}$ and $22.90 \mathrm{mg}$ $\mathrm{kg}^{-1}$, respectively, in the first year and as $19.06 \mathrm{mg} \mathrm{kg}^{-1}$ and $18.89 \mathrm{mg} \mathrm{kg}^{-1}$, respectively, in the second year.

Combined analyses showed significant differences in $\mathrm{Zn}$ contents of the years and cultivars. Year $\times$ location, year $\times$ cultivar and year $\times$ location $\times$ cultivar interactions were also found to be significant (Table 3 ). As the average of two years, $\mathrm{Zn}$ contents of the cultivars varied between 18.84 (Akça) and 23.48 (Işık-05) $\mathrm{mg} \mathrm{kg}^{-1}$ with a general average of $20.26 \mathrm{mg} \mathrm{kg}^{-1}$ (Table 4). Average $\mathrm{Zn}$ content was $21.87 \mathrm{mg} \mathrm{kg}^{-1}$ in the first year and $18.97 \mathrm{mg} \mathrm{kg}^{-1}$ in the second year (Table 5). Differences between $\mathrm{Zn}$ contents of the locations were not found to be significant (Table 4). In previous studies, $\mathrm{Zn}$ contents were reported as between 32-42 $\mathrm{mg} \mathrm{kg}^{-1}$ (Elinç 2017), between 14-56 mg kg-1 (Alajaji \& El-Adawy 2006; Erbaş Köse \& Mut 2019; Haq et al. 2007; Kahraman et al. 2015; Mut \& Gulumser 1998; Ozcan et al. 2013; Vandemark et al. 2018). Zinc constitutes a building stone of auxin-like hormones effective in plant growth and development (Kaçar 1984). Under zinc deficiency, Tryptophan decreases and protein synthesis is inhibited, thus quality is negatively influenced.

\section{IRON (FE) CONTENT}

With regard to $\mathrm{Fe}$ contents, significant differences were observed between the years and the cultivars in Afyonkarahisar and between the cultivars in Yozgat. Year $\times$ cultivar interactions were found to be significant in both locations (Table 3). In Afyonkarahisar, Fe contents varied between 41.60 (Hisar) and 46.20 (Iş̧1k-05) $\mathrm{mg} \mathrm{kg}^{-1}$ with a greater value in the first year $\left(45.38 \mathrm{mg} \mathrm{kg}^{-1}\right)$ than in the second year (42.50 $\mathrm{mg} \mathrm{kg}^{-1}$ ). In Yozgat, Fe contents varied between 37.80 (Azkan) and 53.60 (Iş1k-05) $\mathrm{mg} \mathrm{kg}^{-1}$.

Combined analyses showed significant differences in Fe contents of the cultivars. Year $\times$ location, year $\times$ cultivar, location $\times$ cultivar and year $\times$ location $\times$ cultivar interactions were also found to be significant (Table 3 ). As the average of the years, $\mathrm{Fe}$ contents varied between 40.30 
(Hisar) and 49.90 (Iş1k-05) $\mathrm{mg} \mathrm{kg}^{-1}$ with a general average of $46.55 \mathrm{mg} \mathrm{kg}^{-1}$ (Table 4). The differences in Fe contents of the years and the locations were not found to be significant. Chickpea is richer in iron than the other plants and $100 \mathrm{~g}$ chickpea meets the entire iron need of a daily diet (Jukanti et al. 2012). Iron also plays a great role in biological nitrogen fixation. In previous studies, Fe contents of chickpeas were reported as between 24.4 and $88.4 \mathrm{mg} \mathrm{kg}^{-1}$ (Haq et al. 2007; Kahraman et al. 2015; Mut \& Gulumser 1998; Ozcan et al. 2013), and between 48.4 - $56.5 \mathrm{mg} \mathrm{kg}^{-1}$ (Vandemark et al. 2018). Some others reported average Fe content as $77.2 \mathrm{mg} \mathrm{kg}^{-1}$ (Jukanti et al. 2012), as $29.3 \mathrm{mg} \mathrm{kg}^{-1}$ (Daur et al. 2008), as $68.5 \mathrm{mg} \mathrm{kg}^{-1}$ (Arab et al. 2010) as and 49.5. $\mathrm{mg} \mathrm{kg}^{-1}$ (Erbaş Köse \& Mut 2019).

\section{BORON (B) CONTENT}

With regard to $\mathrm{B}$ contents, years, cultivars and year $\times$ cultivar interactions were found to be significant in Afyonkarahisar. On the other hand, significant differences were not observed between the cultivars in Yozgat. Year $x$ cultivar interactions were found to be significant in both locations (Table 3). In Afyonkarahisar, B contents varied between 13.47 (Hisar) and 15.27 (Akça) $\mathrm{mg} \mathrm{kg}^{-1}$ with a greater value in the first year $\left(14.57 \mathrm{mg} \mathrm{kg}^{-1}\right)$ than in the second year (14.03 $\left.\mathrm{mg} \mathrm{kg}^{-1}\right)$. In Yozgat, B contents varied between 12.65 (Azkan) and 14.33 (Akça, Işık-05) $\mathrm{mg} \mathrm{kg}^{-1}$ and the differences between the years were not found to be significant (Table 4).

According to combined analyses for B contents, years, locations, cultivars and year $\times$ cultivar interactions were found to be significant. Average B contents of the cultivars varied between 13.18 (Hisar) and 14.80 (Akça) $\mathrm{mg} \mathrm{kg}^{-1}$ with a general average of $13.83 \mathrm{mg} \mathrm{kg}^{-1}$. Işık-05 cultivar was placed in the same statistical group with Akça cultivar with the greatest B content. With regard to B contents, the first year $\left(14.10 \mathrm{mg} \mathrm{kg}^{-1}\right)$ was greater than the second year (13.64 $\mathrm{mg} \mathrm{kg}^{-1}$ ) (Table 5) and Afyonkarahisar (14.25 mg $\mathrm{kg}^{-1}$ ) was greater than Yozgat (13.39 $\mathrm{mg} \mathrm{kg}^{-1}$ ) (Table 4). Boron plays a significant role in carbohydrate and protein metabolisms of the plants (Marschner 1995). Kahraman et al. (2015) carried out a study with 10 different chickpea cultivars and reported B contents as between $9.44-10.19$ mg kg-1; Ozcan et al. (2013) conducted a study with different legume species and reported the average B content of chickpea as $26.4 \mathrm{mg} \mathrm{kg}^{-1}$.

\section{MANGANESE (MN) CONTENT}

With regard to Mn contents, significant differences were observed between the years and the cultivars in both locations (Table 3). In Afyonkarahisar, Mn contents varied between 16.80 (Çakır) and 20.95 (Yaşa-05) $\mathrm{mg} \mathrm{kg}^{-1}$, the cultivars Akça and Azkan were placed in the same statistical group with Yaşa-05 with the greatest Mn content. In Yozgat, Mn contents varied between 12.83 (Hisar) and 16.68 (Yaşa-05) $\mathrm{mg} \mathrm{kg}^{-1}$, the cultivars Çakır and Işık-05 were placed in the same statistical group with Yaşa-05 with the greatest Mn content (Table 4). In both locations, the first year had greater values than the second year (Table 5).

According to combined analyses for Mn contents, years, locations, cultivars, year $\times$ location, location $\times$ cultivarand year $\times$ location $\times$ cultivar interactions were found to be significant (Table 3). Average Mn contents of the cultivars varied between 14.88 (Hisar) and 18.82 (Yaşa05) $\mathrm{mg} \mathrm{kg}^{-1}$ with a general average of $16.82 \mathrm{mg} \mathrm{kg}^{-1}$ (Table 4). Mn contents were greater in the first year $(19.38 \mathrm{mg}$ $\left.\mathrm{kg}^{-1}\right)$ than in the second year $\left(14.25 \mathrm{mg} \mathrm{kg}^{-1}\right)$ and greater in Afyonkarahisar $\left(18.67 \mathrm{mg} \mathrm{kg}^{-1}\right)$ than in Yozgat (15.04 $\mathrm{mg} \mathrm{kg}^{-1}$ ) (Table 4). Such differences were attributed to better climate conditions of the first year and different responses of the cultivars to ecological conditions. Edible legumes are quite rich in manganese. In previous studies, Mn contents of chickpeas were reported as between 18.5 $-54.5 \mathrm{mg} \mathrm{kg}^{-1}$ (Ceran 2015; Haq et al. 2007; Iqbal et al. 2006; Kahraman et al. 2015; Vandemark et al. 2018).

\section{COPPER (CU) CONTENT}

With regard to $\mathrm{Cu}$ contents, significant differences were observed between the years and the cultivars in Afyonkarahisar and between the cultivars in Yozgat. Year $\times$ cultivar interactions were found to be significant in both locations (Table 3). In Afyonkarahisar, $\mathrm{Cu}$ contents varied between 6.738 (Çakır) and 7.903 (Akça) $\mathrm{mg} \mathrm{kg}^{-1}$ with greater values in the first year $\left(7.819 \mathrm{mg} \mathrm{kg}^{-1}\right)$ than in the second year $\left(6.899 \mathrm{mg} \mathrm{kg}^{-1}\right)$. In Yozgat, $\mathrm{Cu}$ contents varied between 6.170 (Gökçe) and 8.650 (Yaşa-05) mg kg-1 and the differences between the years were not found to be significant (Table 4).

According to combined analyses for $\mathrm{Cu}$ contents, cultivars, year $\times$ location, year $\times$ cultivar, location $\times$ cultivar and year $\times$ location $\times$ cultivar interactions were found to be significant (Table 3). Average $\mathrm{Cu}$ contents of the cultivars varied between 6.873 (Çakır) and 8.076 (Yaşa05) $\mathrm{mg} \mathrm{kg}^{-1}$ with a general average of $7.149 \mathrm{mg} \mathrm{kg}^{-1}$ (Table 4). With regard to average $\mathrm{Cu}$ contents, the differences between the years and the locations were not found to be significant. Such a case indicated different responses of cultivars to years and locations (Table 3 ). Copper plays a significant role in protein and carbohydrate metabolisms. In also plays a role in nitrogen fixation. Under copper deficiency, number of bacteroids decrease, leghemoglobin synthesis and nitrogen fixation is inhibited (Gulumser et al. 2008). In previous studies, $\mathrm{Cu}$ contents of the chickpeas were reported as between 4.85-14.9 mg $\mathrm{kg}^{-1}$ (Alajaji \& El-Adawy 2006; Daur et al. 2008; Haq et al. 2007; Ozcan et al. 2013; Ray et al. 2014).

\section{CORRELATIONS BETWEEN THE INVESTIGATED TRAITS}

This study was conducted with eight different chickpea cultivars at two different locations for two years. Correlations between the investigated traits and resultant 
TABLE 6. Correlations between seed mineral concentrations for eight chickpea cultivars across two years and two locations

\begin{tabular}{|c|c|c|c|c|c|c|c|c|c|c|}
\hline & $\mathrm{P}$ & $\mathrm{S}$ & $\mathrm{Ca}$ & $\mathrm{Mg}$ & $\mathrm{Na}$ & $\mathrm{Zn}$ & $\mathrm{Fe}$ & $\mathrm{B}$ & $\mathrm{Mn}$ & $\mathrm{Cu}$ \\
\hline K & $0.820 *$ & -0.674 & 0.591 & $0.895 * *$ & 0.535 & 0.672 & $0.871 * *$ & 0.705 & $0.820^{*}$ & 0.656 \\
\hline $\mathrm{P}$ & & -0.494 & 0.208 & $0.742 *$ & 0.346 & 0.647 & $0.811^{*}$ & 0.318 & $0.857 * *$ & $0.772 *$ \\
\hline S & & & $-0.766^{*}$ & $-0.753^{*}$ & -0.651 & -0.595 & $0.734 *$ & $-0.792 *$ & -0.511 & -0.403 \\
\hline $\mathrm{Ca}$ & & & & $0.772 *$ & $0.888^{* *}$ & 0.224 & 0.489 & $0.958^{* *}$ & 0.380 & 0.261 \\
\hline $\mathrm{Mg}$ & & & & & $0.785^{*}$ & 0.455 & $0.746^{*}$ & $0.796^{*}$ & $0.806^{*}$ & $0.713^{*}$ \\
\hline $\mathrm{Na}$ & & & & & & 0.087 & 0.444 & $0.853^{* *}$ & 0.439 & 0.507 \\
\hline $\mathrm{Zn}$ & & & & & & & $0.914^{* *}$ & 0.278 & 0.352 & 0.159 \\
\hline $\mathrm{Fe}$ & & & & & & & & 0.557 & 0.600 & 0.449 \\
\hline B & & & & & & & & & 0.512 & 0.316 \\
\hline $\mathrm{Mn}$ & & & & & & & & & & $0.783^{*}$ \\
\hline
\end{tabular}

K: potassium, P: phosphorus, S: sulfur, Ca: calcium, Mg: magnesium, Na: sodium, Zn: zinc, Fe: iron, B: boron, Mn: manganese, Cu: copper

correlation coefficients are provided in Table $6 . \mathrm{K}$ contents had significant positive correlations with $\mathrm{P}\left(0.820^{*}\right), \mathrm{Mg}$ $\left(0.895^{* *}\right), \mathrm{Fe}\left(0.871^{* *}\right)$ and $\mathrm{Mn}\left(0.820^{*}\right)$ contents. P contents had significant positive correlations with $\mathrm{Mg}$ $(0.742 *), \mathrm{Fe}\left(0.811^{*}\right), \mathrm{Mn}\left(0.857^{* *}\right)$ and $\mathrm{Cu}(0.772 *)$ contents. S contents had significant positive correlations with $\mathrm{Fe}\left(0.734^{*}\right)$ content, but had significant negative correlations with $\mathrm{Ca}\left(-0.766^{*}\right), \mathrm{Mg}\left(-0.753^{*}\right)$ and $\mathrm{B}$ $(-0.792 *)$ contents. Ca content has significant positive correlations with $\mathrm{Mg}(0.772 *), \mathrm{Na}(0.888 * *)$ and $\mathrm{B}$ $\left(0.958^{* *}\right)$ contents; $\mathrm{Mg}$ content with $\mathrm{Na}\left(0.785^{*}\right), \mathrm{Fe}$ $\left(0.746^{*}\right), \mathrm{B}\left(0.796^{*}\right), \mathrm{Mn}\left(0.806^{*}\right)$ and $\mathrm{Cu}\left(0.713^{*}\right)$ contents; Na content with B $\left(0.853^{* *}\right)$ content; $\mathrm{Zn}$ content with $\mathrm{Fe}(0.914 * *)$ content and $\mathrm{Mn}$ content with $\mathrm{Cu}\left(0.783^{*}\right)$ content.

Bueckert et al. (2011) reported significant negative correlations between chickpea $\mathrm{Zn}$ content and $\mathrm{Ca}\left(-0.21^{*}\right)$ content; significant positive correlations between $\mathrm{Fe}$ content and $\mathrm{Ca}\left(0.25^{*}\right)$ content, between $\mathrm{Mg}$ content and
Ca $(0.33 *)$ content. Vandemark et al. (2018) reported significant positive correlations of $\mathrm{K}$ content with $\mathrm{P}, \mathrm{S}$ and $\mathrm{Zn}$ contents; significant negative correlations of $\mathrm{B}$ with $\mathrm{Ca}, \mathrm{Fe}$ and $\mathrm{Mg}$ contents; significant positive correlations of $\mathrm{Ca}$ with $\mathrm{Fe}, \mathrm{Mg}$ and $\mathrm{Mn}$ contents; significant negative correlations between $\mathrm{P}$ and $\mathrm{Zn}$ contents; significant positive correlations of $\mathrm{Cu}$ with $\mathrm{Mg}, \mathrm{Mn}, \mathrm{P}, \mathrm{Fe}, \mathrm{S}$ and $\mathrm{Zn}$ contents and significant negative correlations with $\mathrm{Cu}$ content; significant positive correlations of $\mathrm{S}$ with $\mathrm{B}, \mathrm{Cu}, \mathrm{Fe}, \mathrm{Mg}$, $\mathrm{Mn}$ and $\mathrm{P}$ contents.

Biplot graph allows researchers to visually present the relationships between the investigated traits. As presented in Figure 1, principle components were able to explain $82.3 \%$ total variation (IPCA $1-65.0 \%$ and IPCA $2-17.3 \%$ ). In biplot graphs, cultivars were gathered under three groups. The first group was composed of Gökçe, Akçin-91, Azkan and Hisar cultivars and they were prominent with their S contents. The second group was composed only of Çakır cultivar and it was stable with regard to all elements.

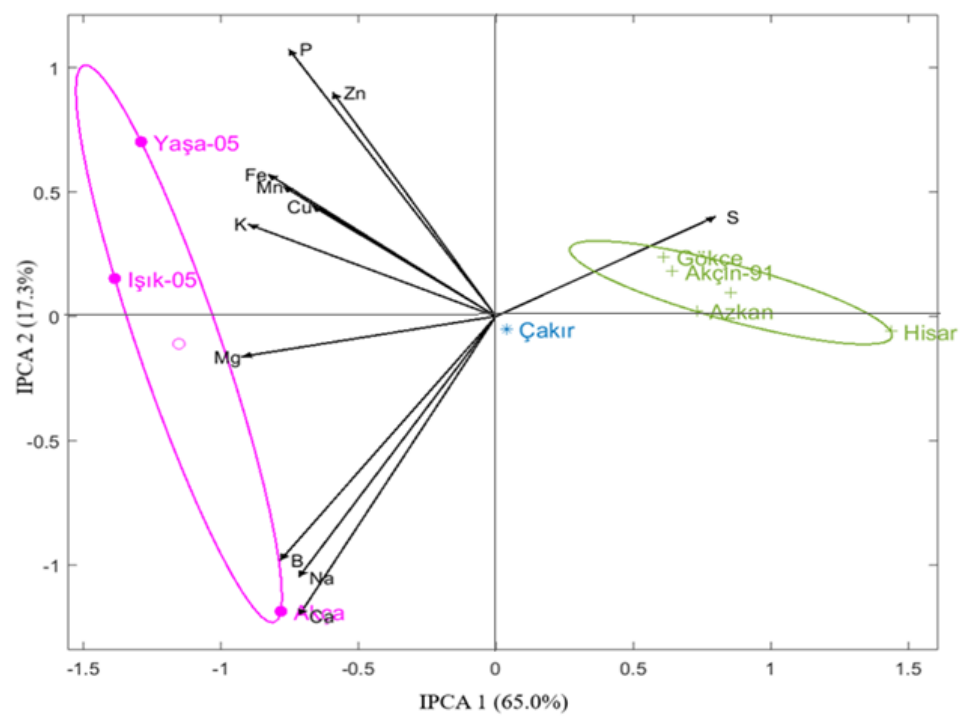

FIGURE 1. Biplot graph showing relationships between minerals and cultivars 
The third group was composed of Yaşa-05, Işık-05 and Akça cultivars and they were prominent with the other elements apart from S. In the third group, Akça had better values for $\mathrm{B}, \mathrm{Na}$ and $\mathrm{Ca}$ contents, Yaşa-05 and Işık-05 cultivars had better values for $\mathrm{P}, \mathrm{Zn}, \mathrm{Fe}, \mathrm{Cu}, \mathrm{Mn}, \mathrm{Zn}, \mathrm{Mg}$ and $\mathrm{K}$ contents.

\section{CONCLUSION}

Considering the locations, Afyonkarahisar had greater K, $\mathrm{S}, \mathrm{Mg}, \mathrm{B}$ and $\mathrm{Mn}$ contents than Yozgat, but Yozgat was prominent with $\mathrm{Ca}$ content. With regard to years on the other hand, 2015 had greater Zn, B and Mn contents, but 2016 had greater Ca content. Such a case was attributed to differences in climate parameters of the locations and the years and differences in soil characteristics of the locations. Locations were not significantly different with regard to $\mathrm{P}, \mathrm{Na}, \mathrm{Zn}, \mathrm{Fe}$ and $\mathrm{Cu}$ contents and years were not significantly different with regard to $\mathrm{K}, \mathrm{P}, \mathrm{S}, \mathrm{Mg}, \mathrm{Na}, \mathrm{Fe}$ and $\mathrm{Cu}$ contents. With regard to average mineral contents of the cultivars, Yaşa-05 cultivar had K, P, S, Mg, Mn and $\mathrm{Cu}$ contents greater than the averages and Işık-05 cultivar had greater $\mathrm{K}, \mathrm{P}, \mathrm{Ca}, \mathrm{Mg}, \mathrm{Na}, \mathrm{Zn}, \mathrm{Fe}$ and $\mathrm{B}$ contents greater than the averages. Except for S, Hisar cultivar had the lowest values for all minerals. Based on location averages, cultivars were gathered under three groups in biplot graph. The first group, composed of Gökçe, Akçin-91, Azkan and Hisar cultivars, was prominent with S content; the second group, composed of Çakır cultivar, was stable for all minerals and the third group, composed of Yaşa-05, Iş1k-05 and Akça cultivars, was prominent with all elements, except for S. Of the cultivars in the third group, Akça had better outcomes for $\mathrm{B}, \mathrm{Na}$ and $\mathrm{Ca}$ contents, Yaşa-05 and Iş1k-05 cultivars for $\mathrm{P}, \mathrm{Zn}, \mathrm{Fe}, \mathrm{Cu}, \mathrm{Mn}, \mathrm{Zn}, \mathrm{Mg}$ and $\mathrm{K}$ contents. It was concluded based on present findings that mineral contents of chickpeas varied based on climate, soil conditions and cultivar genetics.

\section{REFERENCES}

Akdag, C. 2001. Determination of sowing time with chickpea varieties that will provide high yield in Tokat. JAFAG 59: 19.

Alajaji, S.A. \& El-Adawy, T. 2006. Nutritional composition of chickpea (Cicer arietinum L.) as affected by microwave cooking and other traditional cooking methods. Journal of Food Composition and Analysis 19: 806-812.

Arab, E.A.A., Helmy, I.M.F. \& Bareh, G.F. 2010. Nutritional evaluation and functional properties of chickpea (Cicer arietinum L.) flour and the improvement of spaghetti produced from its. Journal of American Science 6(10): 1055-1072.

Bayrak, H. \& Onder, M. 2017. Determination of agricultural, technological and nutritional characteristics of local populations and varieties of chickpea (Cicer arietinum L.) cultivated in Konya ecological region. Journal of Field Crops Central Research Institute 26: 52-61.

Budag, C. 2009. Feed grain legumes and usage in ruminant nutrition. Yuzuncu Yil University Journal of the Institute of Natural and Applied Sciences 14(2): 88-101.
Bueckert, R.A., Thavarajah, P. \& Pritchard, J. 2011. Phytic acid and mineral micronutrients in field-grown chickpea (Cicer arietinum L.) cultivars from Western Canada. Eur. Food Res. Technol. 233(2): 203-212.

Ceran, F. 2015. Determination of some agricultural characteristics on chickpea (Cicer arietinum L.) cultivars that are sown at different periods. PhD Thesis. Selcuk University, Konya, Turkey (Unpublished).

Daur, I., Khan, I.A. \& Jahangir, M. 2008. Nutritional quality of roasted and pressure-cooked chickpea compared to raw (Cicer arietinum L.) seeds. Sarhad J. Agric. 24(1): 117.

Elinç, F. 2007. Plant Nutrition and Soil Fertility. Ondokuz Mayis University, Faculty of Agriculture. Textbook. No: 51.

Erbaş Köse, Ö.D. \& Mut, Z. 2019. Determination of mineral content of chickpea varieties and lines grown in Turkey. Derim. 36(1): 73-78.

FAO. 2017. Statistical Databases. http://faostat.fao.org/site/567/ default.aspx\#ancor. Accessed on 1st April 2019.

Gomez, K.A. \& Gomez, A.A. 1984. Statistical Procedure for Agricultural Research. 2nd ed. New York: Wiley.

Gulumser, A., Bozoglu, H. \& Peksen, E. 2008. Edible Legumes. Ondokuz Mayss University Agriculture Faculty. Texbook. No: 27.

Hangen, L. \& Bennink, M.R. 2002. Consumption of black beans and navy beans (Phaseolus vulgaris) reduced azoxymethane-induced colon cancer in rats. Nutr. Cancer 44: 60-65.

Haq, M.Z.U., Iqbal, S., Shakeel, A., İmran, M., Niaz, A. \& Bhanger, M. 2007. Nutritional and compositional study of desi chickpea (Cicer arietinum L.) cultivars grown in Punjab. Pakistan Food Chemistry 105(4): 1357-1363.

Iqbal, A., Khalil, I.A., Ateeq, N. \& Khan, M.S. 2006. Nutritional quality of important food legumes. Food Chemistry 97: 331-335.

Jukanti, A.K., Gaur, P.M., Gowda, C.L.L. \& Chibbar, R.N. 2012. Nutritional quality and health benefits of chickpea (Cicer arietinum L.): A review. British Journal of Nutrition 108(S1): 11-26.

Kacar, B. 1984. Plant Nutrition. AÜ Faculty of Agriculture Publications. Textbook. No: 5090. p. 317.

Kacar, B. \& Katkat, A.V. 1998. Plant Nutrition. Uludag University Pub No: 127 . Vipaş Press: 3, Bursa.

Kahraman, A., Ceyhan, E. \& Harmankaya, M. 2015. Nutritional variation and drought tolerance in chickpeas (Cicer arietinum L.). J. Elem. 20(2): 331-341.

Khetarpaul, N. 2018. Total mineral content present (calcium, magnesium, potassium, phosphorus, iron, zinc, manganese, copper, and boron and nickel) in leaves of Desi and Kabuli chickpea varieties (on dry matter basis). IJCS 6(2): 633635.

Lee, S.C., Prosky, L. \& Devries, J.W. 1992. Determination of total, soluble, and insoluble dietary fibre in foods-enzymatic-gravimetric method, mes-tris buffer: Collaborative study. Journal of $A O A C$ International 75: 395-416.

Marschner, H. 1995. Mineral Nutrition of Higher Plants. 2nd ed. New York: Academic Press. pp. 379-396.

Mut, Z. \& Gulumser, A. 1998. The effects of bacteria inoculation, zinc and molybdenum application on some quality traits of Damla-89 chickpea cultivar. Ondokuz Mayis University Faculty of Agriculture Journal 20(2): $1-10$. 
Ozcan, M.M., Dursun, N. \& Juhaimi, F.A. 2013. Macro-and microelement contents of some legume seeds. Environ. Monit. Assess. 185(11): 9295-9298.

Ray, H., Bett, K., Taran, B., Vandenberg, A., Thavarajah, D. \& Warkentin, T. 2014. Mineral micronutrient content of cultivars of field pea, chickpea, common bean, and lentil grown in Saskatchewan, Canada. Crop Sci. 54(4): 16981708.

SAS, INC SAS/STAT users' guide release 7.0. 1998. Cary, NC, USA.

TUIK. 2017. Agricultural statistics database. Ankara: Turkish Statistical Institute. www.tuik.gov.tr. Accessed on 1st May 2019.

Vandemark, G.J., Grusak, M.A. \& Mcgee, R.J. 2018. Mineral concentrations of chickpea and lentil cultivars and breeding lines grown in the US Pacific Northwest. The Crop Journal 6(3): 253-262.

Viswanathan, B. \& Sudha, K. 1989. Photoelectrochemical properties of platinised $\mathrm{TiO}_{2}$. Asian Journal of Chemistry 1(2): 129.

Wang, N. \& Daun, J.K. 2004. The chemical composition and nutritive value of Canadian pulses. Canadian Grain Commission. pp. 19-29.

Wang, N., Hatcher, D.W., Tyler, R.T., Toews, R. \& Gawalko, E.J. 2010. Effect of cooking on the composition of beans
(Phaseolus vulgaris L.) and chickpeas (Cicer arietinum L.). Food Research International 43(2): 589-594.

Wood, A. \& Grusak, M.A. 2007. Nutritional value of chickpea. In Chickpea Breeding and Management, edited by Yadav, S.S., Redden, B., Chen, W. \& Sharma, B. Wallingford, UKC: AB International. pp. 101-142.

Yalçın, F., Mut, Z. \& Erbas Kose, O.D. 2018. Determination of suitable chickpea (Cicer arietinum L.) varieties to provide high yield in Afyonkarahisar and Yozgat Conditions. JAFAG 35(1): 46-59.

Department of Field Crops

Faculty of Agriculture and Nature Sciences

Bilecik Şeyh Edebali University

11230 Bilecik

Turkey

*Corresponding author; email: ozgedoganay.erbas@bilecik. edu.tr

Received: 20 August 2019

Accepted: 25 October 2019 
